\title{
Effects of restoration habitats on snake species of Dghoumes National Park (Tunisia)
}

\author{
Ernesto Filippi
}

Via Aurelia 18, 00040 Ariccia (Rome) Italy; e-mail: ernesto.flp@gmail.com

\begin{abstract}
Dghoumes National Park (DNP) is an important protected area located in South Tunisia. This region is characterized by desertification and habitat degradation, mainly caused by climate changes and overgrazing by domestic and semi-domestic livestock. Habitat regeneration, protection of native wildlife and reintroduction of some animal species are at the centre of the activity of this protected area. This article summarizes the results of the first study carried out on the snakes inhabiting this National Park. The study aimed at working out the first checklist of the species and at making a preliminary analysis of the consequences of habitat restoration on the snake species inside the National Park.
\end{abstract}

KEY WORDS Desertification; habitat alteration; habitat restoration; Snakes; Tunisia.

Received 19.05.2019; accepted 02.07.2019; published online 20.08.2019.

\section{INTRODUCTION}

Desertification, the process of semiarid ecosystem deterioration, including drought, soil degradation and vegetation loss in arid environments, covers a wide variety of interactive phenomena, both natural and anthropogenic (Hillel \& Rosenzweig, 2002). This process is widespread and expanding, also in North Africa (Geist \& Lambin, 2004). Past studies, in areas affected by this process, have demonstrated that fauna abundance and diversity decline are a result of vegetation loss (see, for example for birds Bowen \& Kruse, 1993, and for lizards Martin \& Lopez, 2002). In these degraded areas, measures for habitat protection or the rehabilitation of cover plant can help gradually restore wildlife populations (see, for example, Attum et al., 2006 for lizards).

Dghoumes National Park (DNP) is located in South Tunisia (N 3403'00.09”, E 8³3'37.30"), close to Tozeur (Fig. 1), in a territory affected by desertification and habitat degradation, mainly caused by climate changes and overgrazing by domestic and semi-domestic livestock (goats, sheep and dromedaries in a semi-wild state) (Woodfine et al., 2009). DNP protects a small (7,000 ha), but remarkably diverse, remnant of sub-desertic continental steppe in a transition zone between the central steppe region and the desert in the South (Le Houérou, 2001; Olsen et al., 2001; El Ghaib, 2004). DNP comprises two distinct topographical areas: (1) an intermediate plain marked by a series of ephemeral water courses (wadis) running North to South ( 4,000 ha); and (2) a mountain chain to the north that rises steeply from the plain to an average altitude of around $370 \mathrm{~m}$ above sea level $(\sim 3,000 \mathrm{ha})$ (El Ghaib, 2004; Woodfine et al., 2009). Basically the intermediate plan of DNP is a subrectangular and fenced flat area, bordering north the mountain chain and south the salt lake "chott El Jerid". In 
DNP some activities are in progress to contrast desertification, to remove the problems that are causing the habitat degradation and to protect wildlife. The activities carried out in the intermediate plan of DNP can briefly be summarized as follows: i) intervention of vegetation regeneration (Figs. 2, 3); ii) interdiction of grazing by domestic and semi-domestic livestock which in the past caused extensive overgrazing; iii) creation of two small storage ponds; iv) reintroduction of some mammal and bird species, e.g. scimitar-horned oryx, Oryx dammah (Cretzschmar, 1827) Mammalia Bovidae, an antelope extinct in nature.

Some studies were realized in DNP to evaluate the consequences of these activities of wildlife and habitat conservation. In this paper I report the results of the first study on snake species that was aimed to deliver a check list of snake species and a preliminary assessment on the effect of the measures of habitat restoration on snake species. This study was part of a wider monitoring survey on reptiles and amphibians (see also Filippi et al., 2011; Filippi \& Petretto, 2013), carried out from 2010 to 2014.

\section{MATERIAL AND METHODS}

With the assistance of National Park rangers I searched for snakes along randomized routes inside DNP in intermediate plain $(\sim 4,000 \mathrm{ha})$ and in adjacent areas, located to the East $(\sim 2,000 \mathrm{ha})$ and West $(\sim 2,000 \mathrm{ha})$ outside DNP, immediately close to the fence delimiting DNP. On some occasion I also carried out the survey in the mountain chain inside DNP. Capture was made by hand and/or with the help of professional tools (sticks and hooks). Data were gathered within 233 hours (28 days in total, divided in 7 surveys: October 2010, April and September 2011, September 2012, May and September 2013, May 2014), and I made any effort to maintain the same standards throughout the different days (79 hour/day).

In order to estimate the completeness of the inventory of the snakes I calculated the estimated species using the program EstimateS ver. 9.1.0 (see Colwell e al., 2004). Since the analysis was performed by using abundance of the species, I used the non-parametric estimators ACE and Chao 1 (Luja et al., 2017).
To measure snakes frequency, I divided the total number of snakes observed by the effort in the field (numbers of hours spent in searching for snakes). Since effort in the field inside DNP intermediate plain and effort in the field outside DNP intermediate plain was different, for any comparisons between the numbers of snakes observed and expected inside and outside DNP, during the field study, I used the same method described in Seigel (1992) which permits the calculation of the expected numbers of snakes in relation to capture effort (see also Filippi, 2003). I first determined the relative sampling effort per area by dividing the number of hours spent in each area by the total number of hours spent in the field during the entire research period. Using a null hypothesis of equal activity among the areas, I then generated the expected number of snakes active inside and outside DNP by multiplying the total number of snakes found active during the study by the relative sampling effort for each area. Finally, observed and expected values were compared by using a $\chi^{2}$-test.

Snake species diversity and dominance inside and outside DNP were calculated using Margalef's Diversity Index and the Berger-Parker index (Magurran, 1988):

$$
\begin{aligned}
& \text { Div. }=(\mathrm{S}-1) / \operatorname{lnN}(\text { Margalef's Diversity Index }) \\
& \text { Dom. }=\mathrm{N}_{\max } / \mathrm{N}(\text { Berger }- \text { Parker index })
\end{aligned}
$$

where $\mathrm{S}$ is the total number of species, $\mathrm{N}$ is the total number of individuals and Nmax is the total number of the individuals of the most abundant species.

I also set up diurnal randomized transects inside and outside the intermediate plain of DNP to evaluate potential quantitative differences in number of Acanthodactylus boskianus (Daudin, 1803). This lizard, which is ubiquitary and very common in DNP intermediate plain, is reported to be a part of the diet of all snake species inhabitants in DNP (Chpakowsky \& Chnéour, 1953; Scheich et al., 1996). I realized these diurnal standardized transects (individuals per $\mathrm{km})$ in four areas $(\sim 600 \mathrm{ha}$ each) of the intermediate plain: two areas within DNP and two adjacent areas outside, one on the West and the other on the East side. Line-transect relied on the following critical assumptions (Buckland et al., 2001): each transect in each area, 
was randomly selected, sampled only once and in only one direction, at a constant rate of approximately 2-2.5 km per hour; lizards were detected prior to responsive movement and detections were independent; measurements were recorded accu- rately, with no observer bias; twenty one replicate transects, $1 \mathrm{~km}$ each, were surveyed on foot in each area. The perpendicular distance from transects to lizards was calculated for each animal sighted.

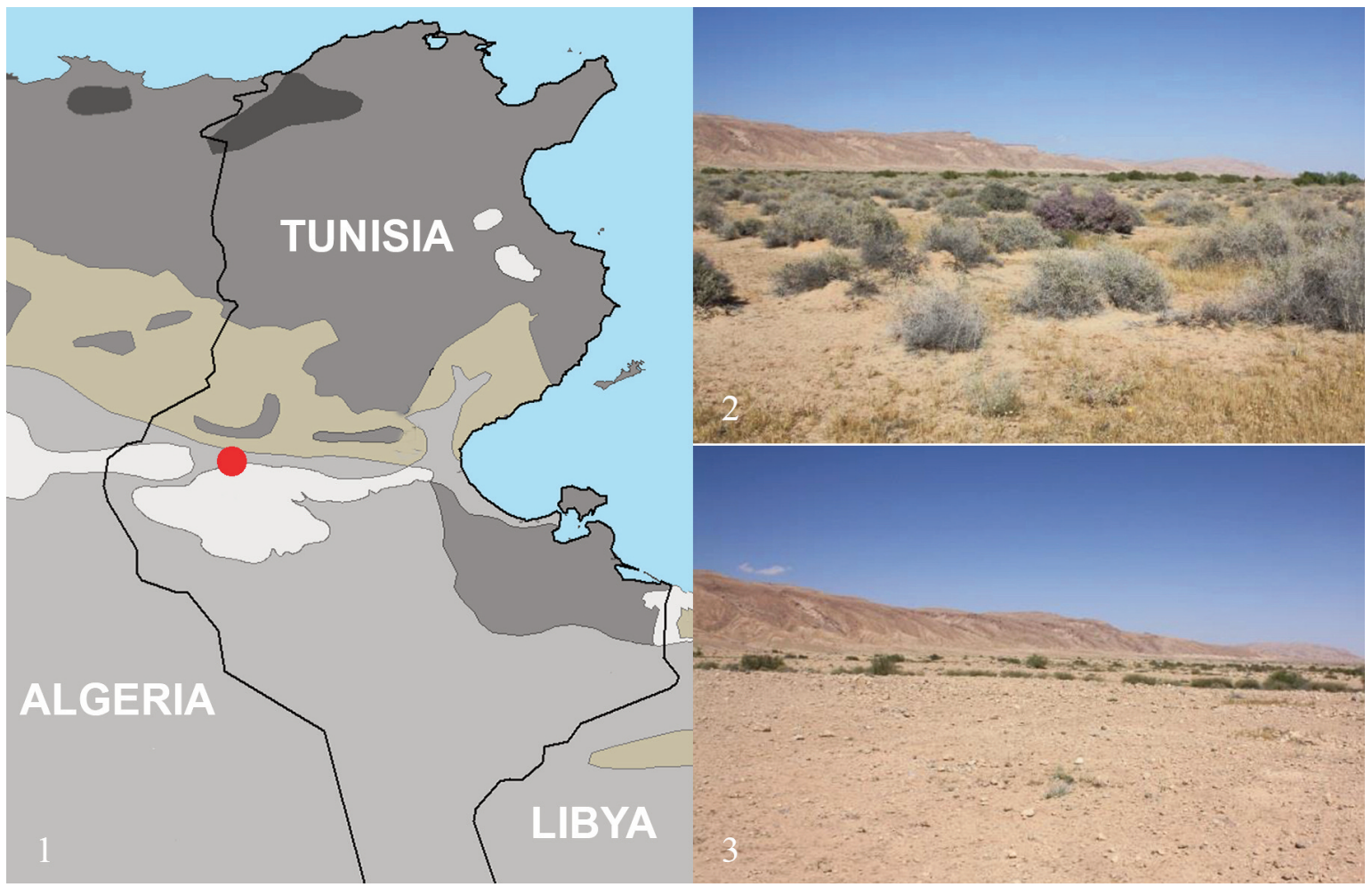

Figure 1. Localization of the Dghoumes National Park (DNP), S-Tunisia. Figures 2, 3. Differences in vegetation cover between the inside (Fig. 2) and the outside (Fig. 3) of DNP. For more details, see the text.

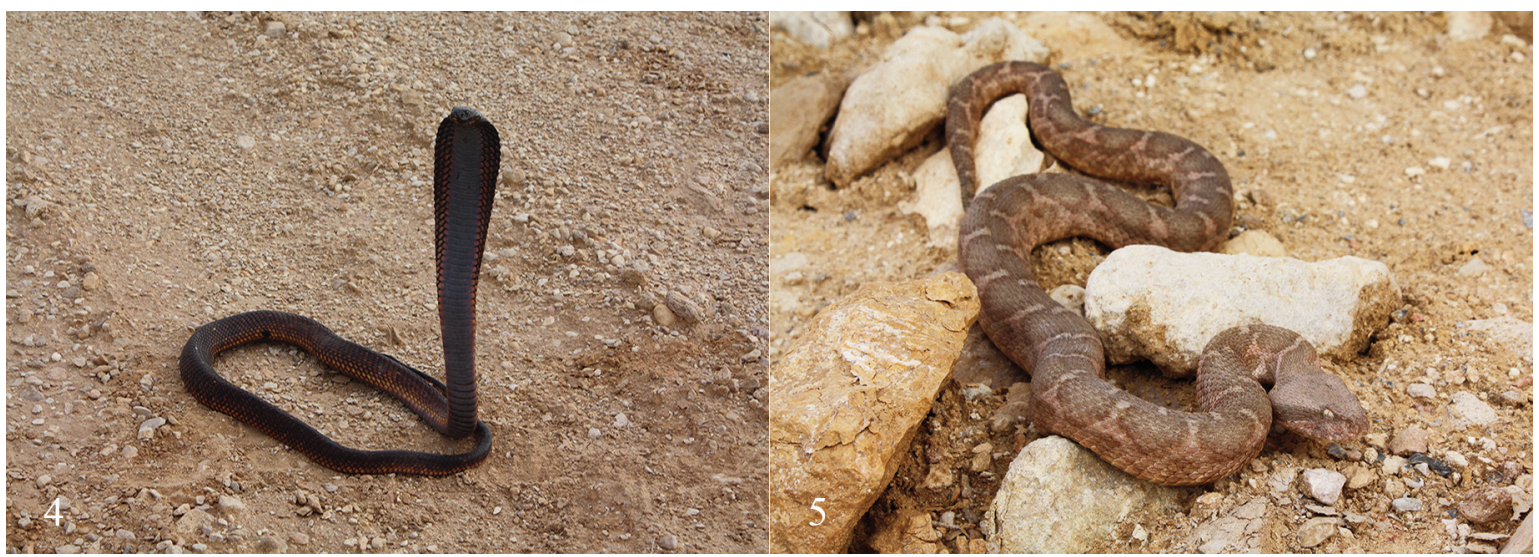

Figures 4, 5. Two of the snake species observed at DNP: Naja haje (Linnaeus, 1758) (Fig. 4) and Daboia deserti (Anderson, 1892) (Fig. 5) 


\begin{tabular}{|c|c|c|c|c|c|}
\hline REPTILES & $\begin{array}{c}\text { Plain Inside } \\
\text { National } \\
\text { Park }\end{array}$ & $\begin{array}{c}\text { Plain } \\
\text { Outside } \\
\text { National } \\
\text { Park }\end{array}$ & $\begin{array}{c}\text { Hill inside } \\
\text { National } \\
\text { Park }\end{array}$ & $\begin{array}{l}\text { IUCN Red List } \\
\text { (IUCN 2016.3) }\end{array}$ & $\begin{array}{l}\text { Cox et al. } \\
(2006)\end{array}$ \\
\hline \multicolumn{6}{|l|}{ Gekkonidae } \\
\hline $\begin{array}{l}\text { Stenodactylus } \\
\text { sthenodactylus } \\
\text { (Lichtenstein, 1823) }\end{array}$ & + & + & & $\begin{array}{l}\text { This taxon has not yet } \\
\text { been assessed for the } \\
\text { IUCN Red list }\end{array}$ & $\begin{array}{l}\text { Least } \\
\text { Concern }\end{array}$ \\
\hline $\begin{array}{l}\text { Tarentola fascicularis } \\
\text { wolfgangi Joger } \\
\text { et Bshaenia, } 2010\end{array}$ & + & & + & $\begin{array}{l}\text { This taxon has not yet } \\
\text { been assessed for the } \\
\text { IUCN Red list }\end{array}$ & $\begin{array}{l}\text { Not } \\
\text { Evaluated }\end{array}$ \\
\hline \multicolumn{6}{|l|}{ Agamidae } \\
\hline $\begin{array}{l}\text { Trapelus mutabilis } \\
\text { (Merrem, 1820) }\end{array}$ & + & + & & $\begin{array}{l}\text { This taxon has not yet } \\
\text { been assessed for the } \\
\text { IUCN Red list }\end{array}$ & $\begin{array}{l}\text { Least } \\
\text { Concern }\end{array}$ \\
\hline $\begin{array}{l}\text { Uromastix } \\
\text { acanthinura } \\
\text { Bell, } 1825\end{array}$ & + & & & $\begin{array}{l}\text { This taxon has not yet } \\
\text { been assessed for the } \\
\text { IUCN Red list }\end{array}$ & $\begin{array}{l}\text { Near } \\
\text { Threatened }\end{array}$ \\
\hline \multicolumn{6}{|l|}{ Scincidae } \\
\hline $\begin{array}{l}\text { Chalcides ocellatus } \\
\text { (Forsskål, 1775) }\end{array}$ & + & & & $\begin{array}{l}\text { This taxon has not yet } \\
\text { been assessed for the } \\
\text { IUCN Red list }\end{array}$ & $\begin{array}{l}\text { Least } \\
\text { Concern }\end{array}$ \\
\hline $\begin{array}{l}\text { Sphenops boulengeri } \\
\text { (Anderson, 1892) }\end{array}$ & + & + & & $\begin{array}{l}\text { This taxon has not yet } \\
\text { been assessed for the } \\
\text { IUCN Red list }\end{array}$ & $\begin{array}{l}\text { Least } \\
\text { Concern }\end{array}$ \\
\hline \multicolumn{6}{|l|}{ Varanidae } \\
\hline $\begin{array}{l}\text { Varanus griseus } \\
\text { (Daudin, 1803) }\end{array}$ & + & & & $\begin{array}{l}\text { This taxon has not } \\
\text { been assessed for the } \\
\text { IUCN Red list }\end{array}$ & $\begin{array}{l}\text { Least } \\
\text { Concern }\end{array}$ \\
\hline \multicolumn{6}{|l|}{ Lacertidae } \\
\hline $\begin{array}{l}\text { Acanthodactylus } \\
\text { boskianus } \\
\text { (Daudin, 1802) }\end{array}$ & + & + & + & $\begin{array}{l}\text { This taxon has not } \\
\text { been assessed for the } \\
\text { IUCN Red list }\end{array}$ & $\begin{array}{l}\text { Least } \\
\text { Concern }\end{array}$ \\
\hline $\begin{array}{l}\text { Acanthodactylus } \\
\text { dumerili (Milne- } \\
\text { Edwards, 1829) }\end{array}$ & + & & & $\begin{array}{l}\text { This taxon has not } \\
\text { been assessed for the } \\
\text { IUCN Red list }\end{array}$ & $\begin{array}{l}\text { Least } \\
\text { Concern }\end{array}$ \\
\hline \multicolumn{6}{|l|}{ Colubridae } \\
\hline $\begin{array}{l}\text { Hemorrhois algirus } \\
\text { (Jan, 1863) }\end{array}$ & + & & & Least Concern & $\begin{array}{l}\text { Least } \\
\text { Concern }\end{array}$ \\
\hline \multicolumn{6}{|l|}{ Lamprophiidae } \\
\hline $\begin{array}{l}\text { Malpolon insignitus } \\
\text { (Geoffroy Saint- } \\
\text { Hilaire, 1827) }\end{array}$ & + & & & $\begin{array}{l}\text { This taxon has not yet } \\
\text { been assessed for the } \\
\text { IUCN Red list }\end{array}$ & $\begin{array}{l}\text { Least } \\
\text { Concern }\end{array}$ \\
\hline $\begin{array}{l}\text { Psammophis shokari } \\
\text { (Forsskål, 1775) }\end{array}$ & + & & + & $\begin{array}{l}\text { This taxon has not yet } \\
\text { been assessed for the } \\
\text { IUCN Red list }\end{array}$ & $\begin{array}{l}\text { Least } \\
\text { Concern }\end{array}$ \\
\hline $\begin{array}{l}\text { Rhagerhis moilensis } \\
\text { (Reuss, 1834) }\end{array}$ & + & & & $\begin{array}{l}\text { This taxon has not yet } \\
\text { been assessed for the } \\
\text { IUCN Red list }\end{array}$ & $\begin{array}{l}\text { Least } \\
\text { Concern }\end{array}$ \\
\hline \multicolumn{6}{|l|}{ Elapidae } \\
\hline $\begin{array}{l}\text { Naja haje } \\
\text { (Linnaeus, 1758) }\end{array}$ & + & + & + & $\begin{array}{l}\text { This taxon has not yet } \\
\text { been assessed for the } \\
\text { IUCN red list }\end{array}$ & $\begin{array}{l}\text { Least } \\
\text { Concern }\end{array}$ \\
\hline \multicolumn{6}{|l|}{ Viperidae } \\
\hline $\begin{array}{l}\text { Daboia deserti*** } \\
\text { (Anderson, 1892) }\end{array}$ & & & + & Near Threatened & $\begin{array}{l}\text { Near } \\
\text { Threatened }\end{array}$ \\
\hline $\begin{array}{l}\text { Cerastes cerastes } \\
\text { (Linnaeus, 1758) }\end{array}$ & + & + & & $\begin{array}{l}\text { This taxon has not yet } \\
\text { been assessed for the } \\
\text { IUCN Red list }\end{array}$ & $\begin{array}{l}\text { Least } \\
\text { Concern }\end{array}$ \\
\hline
\end{tabular}

Table 1. Reptiles list of the Dghoumes National Park (DNP). *T. fascicularis is a new subspecies of T. mauritanica, endemic to Central Tunisa from Gafsa (Djebel Orbata) in the West to Bou Hedma in the East, south to Degache and Tozeur at the northern banks of Chott al Djérid (Joger \& Bshaenia, 2010). **Daboia deserti is included in Daboia following Lenk et al. (2001). It is uncertain that Daboia deserti and D. mauritanica (Gray, 1849) are separate species. 


\begin{tabular}{|c|c|c|c|c|c|c|c|}
\hline $\begin{array}{c}\text { Area of } \\
\text { study }\end{array}$ & $\begin{array}{c}\text { Margalef's } \\
\text { Index }\end{array}$ & $\begin{array}{c}\text { Berger- } \\
\text { Parker } \\
\text { index }\end{array}$ & $\begin{array}{c}\text { Seigel's } \\
\text { index }\end{array}$ & $\begin{array}{c}\text { Observed } \\
\text { sample }\end{array}$ & $\begin{array}{c}\text { Expected } \\
\text { sample }\end{array}$ & $\begin{array}{c}\chi^{2}- \\
\text { test }\end{array}$ & $p$ \\
\hline Inside & 1.91 & 0.61 & 0.43 & $19(4)$ & 9.89 & 7.50 & $<0.01$ \\
\hline Outside & 0.63 & 0.80 & 0.57 & $4(1)$ & 13.11 & 5.65 & $<0.05$ \\
\hline
\end{tabular}

Table 2. Values of Margalef's, Berger-Parker, and Seigel's (1992) index, and numbers of snakes (all species are cumulated; diversity index comprises the individuals found dead, which are reported in brackets) observed and expected in the study area. For more details, see the text.

\begin{tabular}{|c|c|c|c|c|c|c|}
\hline $\begin{array}{l}\text { Lizard } / k \\
\text { m }\end{array}$ & $\begin{array}{l}\text { Probability } \\
\text { inside }\end{array}$ & $\begin{array}{l}\text { Probability } \\
\text { outside }\end{array}$ & $\begin{array}{l}\text { Expected } \\
\text { probability } \\
\text { Inside }\end{array}$ & $\begin{array}{l}\text { Expected } \\
\text { probability } \\
\text { outside }\end{array}$ & $\begin{array}{l}\text { Observed } \\
\text { frequency } \\
\text { inside }\end{array}$ & $\begin{array}{l}\text { Observed } \\
\text { frequency } \\
\text { outside }\end{array}$ \\
\hline 0 & 0.35 & 0.65 & 14.7 & 27.3 & 17 & 26 \\
\hline 1 & 0.37 & 0.28 & 15.54 & 11.7 & 15 & 14 \\
\hline 2 & 0.19 & 0.06 & 8.1 & 2.5 & 6 & 2 \\
\hline 3 & 0.07 & 0.01 & 2.8 & 0.36 & 2 & 0 \\
\hline 4 & 0.02 & 0.001 & 0.74 & 0.39 & 1 & 0 \\
\hline 5 & 0.004 & 0.0001 & 0.16 & 0.003 & 0 & 0 \\
\hline 6 & 0.001 & 0.00001 & 0.03 & 0.0002 & 0 & 0 \\
\hline 7 & 0.0001 & 0.0000004 & 0.004 & 0.00001 & 1 & 0 \\
\hline
\end{tabular}

Table 3. Probability (Poisson probability for obtaining the observed value, assuming a Poisson distribution with a mean rate parameter $\lambda_{\text {inside }}=1.05$ and $\lambda_{\text {outside }}=0.43$ ), expected (Poisson) and observed frequencies of lizard individual/ transect $\mathrm{km}$ inside or outside Dghoumes National Park.

\section{RESULTS}

Snakes composition of DNP is 7 species in total (Figs. 4, 5). The ACE and Chao1 estimator predicted seven species each. I summarized, in Table 1 , the snake species and other reptiles recorded. I captured 23 snakes as a whole: 19 inside and 4 outside the National Park. The overall frequency of observation was 0.099 snakes $\mathrm{x}$ hour ${ }^{-1}$, the inside frequency of observation was 0.14 snakes $x$ hour $^{-1}$ and the outside frequency of observation was 0.04 snakes $\mathrm{x}$ hour ${ }^{-1}$.

Cerastes cerastes (Linnaeus, 1758) is the most common snake in this area $(n=12$, individuals captured, $n=6$ females, $n=4$ males and $n=2$ juveniles). The adult sex ratio $(1.5: 1)$ was close to equality, binomial test, $p>0.05$ ) and the frequency of observation was 0.05 individuals $\mathrm{x}$ hour $\left.{ }^{-1}\right)$. In terms of total length (TL) (males $\mathrm{x}=$ $60.2 \pm 5.8 \mathrm{~cm}, \mathrm{n}=4$; females $\mathrm{x}=57.1 \pm 6.8 \mathrm{~cm}$, $\mathrm{n}=6$ ) and snouth vent length (SVL) (males $\mathrm{x}=$ $54.3 \pm 5.3 \mathrm{~cm}, \mathrm{n}=4$; females $\mathrm{x}=52.7 \pm 6.2 \mathrm{~cm}$, $\mathrm{n}=6$ ) no inter-sexual differences was observed in TL (Student $t$ - test, $p>0.05$, df $=8$ ) and SVL $(p=0.68)$ with the males attaining a slightly longer size than females $(p>0.05)$. A significant difference was noticed between males and females in terms of tail length with the males attaining a larger size $(p<0.05)$.

As far as the number of snakes observed inside and outside DNP, with the same field effort, the number of snakes observed exceeded signifi- 
cantly the one expected inside the National Park $\left(\chi^{2}\right.$ -test Yates correction $=7.50, p<0.01, \mathrm{df}=1)$ and was significantly fewer than that expected inside DNP $\left(\chi^{2}\right.$-test Yates correction $=5.65, p<0.05, \mathrm{df}$ $=1)($ see Table 2).

Five individuals, Naja haje (Linnaeus, 1758) (n $=1), C$. cerastes $(\mathrm{n}=2)$, Daboia deserti (Anderson, 1892) $(\mathrm{n}=1)$, Hemorrois algirus (Jan, 1863) $(\mathrm{n}=1)$ were found dead by the author or collected by rangers. The causes of death were different: two were killed by man ( $N$. haje and $D$. deserti), two were road killed outside the National Park $(H$. algirus and $C$. cerastes) and one was killed by $N$. haje $(\mathrm{n}=1)$ (see Filippi \& Petretto, 2013).

The comparison between Berger-Parker, Margalef's and Seigel's index, calculated by using both snakes captured and those found dead, inside and outside DNP, is reported in Table 2.

There is a significant difference in the number of individuals lacertids observed between all areas taken as samples $\left(\chi^{2}\right.$-test $=13.226, p<0.01, \mathrm{df}=$ 3 ), particularly between the areas located inside the National Park and those located outside the National Park $\left(\chi^{2}\right.$-test $=10.903$, Yates correction, $p<$ 0.001 , $\mathrm{df}=1)$, while there is no significant difference between the two areas outside $\left(\chi^{2}\right.$-test $=2$, Yates correction, $\mathrm{p}>0.05, \mathrm{df}=1$,) and the two areas inside the National Park $\left(\chi^{2}\right.$-test $=0.818$, Yates correction, $p>0.05$, $\mathrm{df}=1)$.

The comparison between the frequency of lizard individuals observed per $\mathrm{km}$, the expected frequency and the possibility to obtain the different frequencies observed are reported in Table 3.

\section{RESULTS}

The data gathered have allowed to outline a first check list of DNP snakes, an important area in Southern Tunisia which had not been studied before. The estimators calculated show that this study has probably allowed a total completeness of species richness of this area. The number of snake species of DNP, located in a transition zone between the central steppe region and the desert in the South, is quite consistent with those reported in the two nearest national parks: Bou Hedma National Park, which is located $70 \mathrm{~km}$ north from DNP and is characterized by Mediterranean and semi-arid ecosystem, where 10 snakes species were recorded
(Moldryk, 2003) and in Djebil NP, which is located $100 \mathrm{~km}$ south from DNP and is characterized by desertic ecosystem, where 4 snakes species were recorded (Joger, 2003).

Inside DNP I observed more snake species than outside, the frequency of observations and the diversity index increased, the dominance index decreased and the difference between individual observed and expected was significantly higher. There is also a significant difference in A. boskianus observed, one of the most common prey of all the snakes in this area.

The quantitative analysis and the diversity index (though it is necessary to always consider the theoretical limitations of these index when applied to a low number of species as in the study case, see Hubalek, 2000) suggest that the snakes are not independently and randomly distributed inside and outside DNP. Therefore the collected data indicate, though preliminarily, that the actions to restore the habitat inside DNP have produced positive effects on snake species presence and species richness. The increased availability of food, as seen for lizards, refuges, microhabitats and/or thermoregulatory patches result of the vegetation regeneration could have contributed to this higher snakes species richness. This is more evident if we consider that the analysis of the snakes inside the protected areas could be partially underestimated since the search for snakes is more difficult in some parts of the protected areas which are characterized by a higher vegetation density, following the vegetation restoration interventions and lack of overgrazing by domestic livestock.

The results achieved are consistent with previous studies in desertic areas which showed that the number of invertebrates and lizards is higher in the areas with more vegetation. All this could result in a higher food availability for their predators in the different steps of the trophic chain (Sanchez \& Parmenter, 2002; Attum et al., 2006).

DNP snakes are subject to a series of threats, among which car accidents and intentional killing by man. Considering that there is a touristic project in order to develop this protected area and that some species are declining in other areas (i.e. cobras in the National park Bou Hedma see Joger, 2003), a particular attention shall be devoted to snakes safeguard and the correct information campaign on the importance of these vertebrates. 
In conclusion, the present study provides a first check-list of snake species in DNP and represents the first attempt to evaluate the effects on snakes of habitat restoration in subdesertic areas of Tunisia. However, in order to better quantify the effects of this important phenomenon in subdesertic areas of North Africa it is necessary to carry out further studies both in the same area and in other places with comparable conditions.

\section{ACKNOLEDGMENTS}

This research study was funded and supported by Marwell Wildlife (UK). Researches were realized under authorization of Direction Generales des Forets (Ministere de l'Agriculture et des Ressources Hydrauliques) and the Commissariat Regional de Developpement Agricole (CRDA) Tozeur, Tunisia. In particular, I would like to thank Gian Lorenzo D'Alterio, Abdelkader Chetoui, Tim Woodfine, Marie Petretto, Chokri Essaoui, Guy Parker, and all the staff of Dghoumes National Park, the Commissariat Regional de Developpement Agricole (CRDA) Tozeur and the Direction Generales des Forets (Ministere de l'Agriculture et des Ressources Hydrauliques) for their precious support and assistance. Let me also thank Maria Luce Del Vecchio (Roma, Italy) for her precious help in writing the English version.

\section{REFERENCES}

Attum O., Eason P., Cobbs G. \& Baha El Din S., 2006. Response of a desert lizard community to habitat degradation: Do ideas about habitat specialists/generalists hold? Biological Conservation, 133: 52-62. https://doi.org/10.1016/j.biocon.2006.05.017

Bowen B.S. \& Kruse A.D., 1993. Effects of grazing on nesting by upland sandpipers in southcentral North Dakota. Journal of Wildlife Management, 57: 291301.

Buckland S.T., Anderson D.R., Burnham K.P., Laake J.L., Borchers D.L. \& Thomas L., 2001. Introduction to distance sampling. Oxford University Press, Oxford, $448 \mathrm{pp}$.

Chpakowsky N. \& Chnéour A., 1953. Les serpents de Tunisie. Bulletin de la Société des sciences naturelles de Tunisie, 6: 125-146.

Colwell R.K., Mao C.X. \& Chang J., 2004. Interpolating, extrapolating, and comparing incidence-based species accumulation curves. Ecology, 85: 27172727.

El Ghaïb, 2004. Le Parc National de Dghoumes. In: IRSNB. 2004. Redéploiement et conservation des Antilopes Sahélo-Sahariennes en Tunisie Compterendu de l'Atelier Technique. Douz, Tunisie 18 et 19 avril 2004 version provisoire. Institut royal des Sciences naturelles de Belgique, 63 pp.

Filippi E., 2003. The effects of timbering on the community structure of snakes at a Mediterranean area of central Italy. Amphibia-Reptilia, 24: 75-79. https:// doi.org/10.1163/156853803763806966

Filippi E. \& Petretto M., 2013. Naja haje (Egyptian Cobra) Diet/Ophiophagy. Herpetological Review, 44: 155-156.

Filippi E., Chetoui A., D’Alterio G.L., Parker G. \& Woodfine T., 2011. Bufo boulengeri: field observations on breeding phenology at a new Saharan site in Southern Tunisia. Herpetology Notes, 4: 215-217.

Geist H.J. \& Lambin E.F., 2004. Dynamic causal patterns of desertification. BioScience, 54: 817-829. https:// doi.org/10.1641/0006-3568(2004)054[0817: DCPOD]2.0.CO;2

Hillel D. \& Rosenzweig C., 2002. Desertification in Relation to Climate Variability and Change. Advances in Agronomy, 77: 1-38. https://doi.org/10.1016/S0 065-2113(02)77012-0

Joger U., 2003. Reptiles and Amphibians of Southern Tunisia. Kaupia, 12: 71-81.

Joger U. \& Bshaenia I., 2010. A new Tarentola (Reptilia: Gekkonidae) subspecies endemic to the Tunisia. Bonn zoological Bulletin, 57: 267-274.

Karem A., Ksantini M., Schoenenberger A. \& Waibel T., 1993. Contribution a la Régénération de la Végétation dans le Parcs Nationaux en Tunisie Aride. Imprimerie Arabe de Tunisie.

Hubalek Z., 2000. Measures of species diversity in ecology: an evaluation. Folia Zoologica, 49: 241-260.

Le Houérou H.N., 2001. Biogeography of the arid steppeland north of the Sahara. Journal of Arid Environments. 48: 103-128. https://doi.org/10.1006/jare. 2000.0679

Lenk P., Kalyabina S., Wink M. \& Joger U., 2001. Evolutionary relationships among the true vipers (Reptilia: Viperidae) inferred from mitochondrial DNA sequences. Molecular Phylogenetics and Evolution, 19: 94-104. https://doi.org/10.1006/mpev.2001.0912

Luja V.H., López J.A., Cruz-Elizalde R. \& RamírezBautista A., 2017. Herpetofauna inside and outside from a natural protected area: the case of Reserva Estatal de la Biósfera Sierra San Juan, Nayarit, Mexico. Nature Conservation, 21: 15-38. https://doi.org/10. 3897/natureconservation.21.12875

Magurran A.E., 1988. Ecological diversity and its measurement. Princeton University Press, 192 pp. 
Martin J. \& Lopez P., 2002. The effect of Mediterranean dehesa management on lizard distribution and conservation. Biological Conservation, 108: 213-219. https://doi.org/10.1016/S0006-3207(02)00107-6

Olsen D.M., Dinerstein E., Wikramanayake E.D., Burgess N.D., Powell G.V.N., Underwood E.C., D'Amico J.A., Itoua I., Strand H.E., Morrison J.C., Loucks C.J., Allnutt T.F., Ricketts T.H., Kura Y., Lamoreux J.F., Wettengel W.W., Hedao P. \& Kassem K.R., 2001. Terrestrial Ecoregions of the World: A New Map of Life on Earth. BioScience 51: 933-938. https://doi.org/10.1641/ 0006-3568(2001)051[0933: TEOTWA]2.0.CO;2

Sanchez B.C. \& Parmenter R.R., 2002. Patterns of shrub dwelling arthropods diversity across a desert shrub- land-grassland ecotone: a test of island biogeographic theory. Journal of Arid Environments, 50: 247-265. https://doi.org/10.1006/jare.2001.0920

Schleich H.H., Kästle W. \& Kabisch K., 1996. Amphibians and Reptiles of North Africa. Koeltz, Koenigstein, $627 \mathrm{pp}$.

Seigel R.A., 1992. Ecology of a specialized predator: Regina grahami in Missouri. Journal of Herpetology, 26: $32-37$.

Woodfine T., Zahzah K., Chetoui A., Gilbert T. \& D'Alterio G.L., 2009. Reintroduction of scimitar-horned oryx to Dghoumes National Park, Tunisia. Report prepared for Direction Générales des Forêts, Tunis, $26 \mathrm{pp}$. 